\title{
PERBANDINGAN KADAR LEMAK DAN BERAT JENIS SUSU SAPI PERAH Friesian Holstein (FH) DI BENDUL MERISI, SURABAYA (Dataran Rendah) dan NONGKOJAJAR, PASURUAN (Dataran Tinggi)
}

\author{
Ratna Widyawati ${ }^{1}$, Olan Rahayu Puji Astuti Mussa ${ }^{1}$, M Dzaki Wiranda Pratama ${ }^{1}$, Roeswandono $^{{ }^{*}}$ \\ ${ }^{1}$ Fakultas Kedokteran Hewan, Universitas Wijaya Kusuma Surabaya \\ *Email: atmajaros@uwks.ac.id
}

\begin{abstract}
This study aims to compare the quality of Friesian Holstein (FH) dairy cows in Bendul Merisi, Surabaya (Lowlands) and Nongkojajar, Pasuruan (Highlands), with the physical quality standard of fresh milk which is the national reference or SNI. This study used 60 samples of cow's milk, 30 samples from Bendul Merisi, and 30 samples from Nongkojajar. The sample was tested in the laboratory using the fat content and specific gravity test, the data obtained were calculated using the T-test formula. The data obtained from the average fat content test in Nongkojajar was $3.3685 \%$, and the average fat content in Bendul Meisi was $4.8003 \%$. The average density at Nongkojajar is $1.024767 \mathrm{mg} / \mathrm{dl}$, the average density at Bendul Merisi is $1.28067 \mathrm{mg} / \mathrm{dl}$. Based on the results of statistical calculations resulted in a significant difference $(P<0.01)$ in the fat content test, statistical calculations resulted in a significant difference $(P<0.01)$ in the specific gravity test.
\end{abstract}

Keywords: Friesian Holstein (FH) dairy cows, Specific Gravity.

\section{PENDAHULUAN}

Sapi perah merupakan jenis ternak ruminansia dengan populasi yang tersebarluas diseluruh dunia, penyebaran sapi lebih merata dibandingkan ternak ruminansia yang lainnya. Sapi mempunya kontribusi yang cukup besar untuk kebutuhan manusia di negara berkembang. Khususnya sapi perah, memunyai produksi susu cukup tinggi yang dapt mensuplai kebutuhan susu manusia (Irawan, 2010).

Berpuluh-puluhan tahun susu selalu dijadikam bahan pangan yang dibutuhkan manusia, dikarenakan susu mempunyai manfaat yang dibutuhkan manusia, selain itu susu mempunyai cita rasa yang lezat dan kandungannya sangat dibutuhkan oleh tubuh (Anang,dkk 2010).

Salah satu upaya mengatasi kekurangan suplai dapat dilakukan dengan jalan pengembangan usaha peternakan sapi perah yang masih terpusat di lingkungan dataran sedang sampai tinggi, sehingga menjadi pembatas peningkatan produktivitas ternak karena wilayah negara Indonesia sebagian besar juga terdiri dari dataran rendah.
Potensi produktivitas ternak pada dasarnya dipengaruhi faktor genetik, lingkungan serta interaksi antara genetik dan lingkungan. Faktor genetik yang berpengaruh adalah bangsa ternak,sedangkan faktor lingkungan antara lain pakan, iklim, ketinggian tempat, bobot badan, penyakit, kebuntingan dan jarak beranak, bulan laktasi serta paritas (Nugroho, A, T, K,. dkk. 2010 ).

Solid Non Fat (SNF) merupakan komponen yang menyusun susu disamping air dan lemak atau dapat disebutkan bahwa bahan kering tanpa lemak susu bergantung pada kadar protein, laktosa dan lemak (Utari dkk., 2012). Anjarsari (2010) mengatakan bahwa komposisi kimia yang terdapat pada susu yaitu lemak 3,8\%, protein $3,2 \%$, laktosa $4,7 \%$, abu 0,855 , air $87,25 \%$ dan bahan kering $12,75 \%$.

Tempat ketinggian lokasi usaha peternakan dapat mempengaruhi kualitas produksi sapi perah. Terdapat adanya perbedaan yang nyata antara penampilan produksi ternak di daerah panas (dataran rendah) dengan di daerah dingin (dataran 
tinggi). Perbedaan produktivitas ini berkaitan erat dengan faktor suhu dan kelembaban udara. Interaksi suhu dan kelembaban udara atau "Temperature Humidity Index" (THI) dapat mempengaruhi kenyamanan hidup ternak. Sapi perah jenis Friesian Holstein (FH) akan nyaman pada nilai THI di bawah 72. Apabila interaksi ini melebihi batas ambang ideal hidup ternak dapat menyebabkan terjadinya cekaman/stres panas (Nugroho, A, T, K, dkk. 2010).

Sapi Friesian Holstein $(F H)$ merupakan jenis sapi perah dengan kemampuan produksi susu tertinggi dengan kadar lemak lebih rendah dibandingkan bangsa sapi perah lainya. Produksi susu sapi perah Friesian Holstein $(F H)$ di negara asalnya mencapai 6000-8000 kg//ekor/laktasi, di Inggris sekitar 35\% dari total populasi sapi perah dapat mencapai $8069 \mathrm{~kg} /$ ekor/laktasi .

Komposisi susu umumnya berbeda dari waktu pemerahan yang berbeda pula (Handayani, 2010). Komposisi dalam susu terdiri dari: air, kadar lemak, protein, karbohidrat, mineral, vitamin dan enzim.

Pemberian pakan adalah salah satu faktor yang menentukan keberhasilan peternakan sapi perah. Kuantitas dan kualitas pakan yang diberikan pada sapi perah, merupakan salah satu faktor yang sangat menentukan optimalitas produksi dan komposisi selama laktasi. Meskipun demikian, pemberian pakan harus sesuai dengan bobot badan kadar lemak susu dan produksi susunya, terutama bagi ternak sapi yang telah berproduksi. Kriteria susu segar untuk Indonesia ditetapkan oleh Badan Standarisasi Nasional menjadi Standar Nasional Indonesia bernomor SNI 3141.1:2011. Kandungan lemak dalam susu adalah komponen terpenting disamping protein dimana harga jual susu tergantung pada tinggi rendahnya kandungan lemak pada susu (Anindita dan Soyi, 2017).

Faktor yang mempengaruhi kadar lemak pada susu adalah faktor genetik, pakan, cara pemeliharaan, iklim, masa laktasi, dan kesehatan hewan (Fitriyanto dkk., 2013).

Mutamimah dkk., (2013) menyatakan bahwa kadar lemak dipengaruhi oleh asam asetat yang berasal dari hijauan, sedangkan prekursor asam asetat berasal dari serat kasar yang difermentasi dalam rumen sehingga berubah menjadi VFA yang terdiri dari asetat, butirat dan propionat. Asam asetat yang kemudian masuk dalam sel-sel sekresi ambing dan menjadi lemak susu (Musnandar, 2011).

Ada beberapa faktor yang menyebabkan perubahan berat jenis pada susu yaitu butiran-butiran lemak (globula), laktosa, protein dan garam. Susu yang telah bercampur dengan air maka berat jenisnya akan menurun. Kenaikan berat jenis susu disebabkan karena adanya pelepasan $\mathrm{CO}_{2}$ dan $\mathrm{N}_{2}$ yang terdapat pada susu tersebut (Warni, 2014).

Prinsip uji kadar lemak susu dengan metode Babcock, Gerber dan Te Sa adalah memisahkan lemak dengan cara menambahkan asam sulfat ke dalam susu dan kemudian diikuti pemusingan (sentrifus). Lemak yang terpisah tersebut ditentukan jumlahnya berdasarkan skala yang ada pada alat karena asam sulfat pekat merombak dan melarutkan kasein dan protein lainnya, lemak menjadi cair oleh panas amyl alkohol. Centrifugasi menyebabkan lemak terkumpul dibagian skala dari butyrometer(Gregorius Agung Pradipto 2012).Standar kadar lemak menurut SNI 01-3141-1998 minimum 3,0 \% ini berlaku pada susu segar. Penentuan kadar lemak pada bahan pangan ini dapat menggunakan 3 metode, yaitu metode soxhlet, metode gerber, dan metode babcock. Metodsoxhlet menggunakan sampel kering sedangkan metode gerber dan babcockmenggunakan sampel basah. Metode soxhlet menggunakan sampel keringsedangkan metode gerber dan babcock menggunakan sampel basah (Sudarmadji,2010). Metode yang dilakukan pada praktikum ini adalah metode soxhlet.

Berdasarkan uraian penelitian diatas, dan banyaknya penelitian tentang faktor suhu atau tempat ketinggian dapat mempearuhi kualitas susu sapi, maka dari itu peneliti tertarik untuk melakukan penelitian mengenai Profil Kadar Lemak dan Berat Jenis susu sapi perah Friesian Holstein $(F H)$ di Bendul Merisi, Surabaya, dan di Nongkjajar, Pasuruan 


\section{MATERI DAN METODE}

Jenis penelitian yang digunakan dalam penelitian ini adalah survey dengan

A. Lokasi dan Waktu Penelitian

Lokasi pengambilan sampel diambil dari dua daerah yang berbeda, yaitu di peternakan sapi perah tradisional Bendul Merisi, Surabaya (dataran rendah) dan di peternakan sapi perah tradisional Nongkojajar, Pasuruan (dataran tinggi). Penelitian dilakukan di Laboratorium Kesmavet Fakultas Kedokteran Hewan Universitas Wijaya Kusuma Surabaya. Penelitian dilaksanakan pada bulan juni 2020.

B. Alat dan Bahan

Alat untuk penghitungan kadar lemak adalah butirometer gerber, sumbat karet, kainlap, sentrifus, penangas air dan pipet otomatis. Alat untuk mengukur berat jenis.

Bahan yang digunakan Uji Berat Jenis meliputi sampel susu $500 \mathrm{cc}$. Uji Kadar Lemak meliputi sample susu $11 \mathrm{cc}, \mathrm{H} 2 \mathrm{SO} 4$ 90- $92 \%$ dan amyl alkohol.

C. Prosedur Penelitian

Melakukan perbandingan kadar lemak dan berat jenis susu dari dua tempat yaitu Nongkojajar Pasuruan dan Bendul Merisi Surabya dengan menggunakan analisis uji-T.

\section{HASIL}

Berdasarkan hasil pemeriksaan kadar lemak, berat jenis pada susu sapi FH yang mana 30 sampel berasal dari KPSP Nongkojajar dan 30 sampel berasal dari Bendul Merisi disajikan dalam tabel berikut.

Tabel 1. Hasil nilai rata-rata kadar lemak

\begin{tabular}{lcc}
\hline Perlakuan & Sampel & $\begin{array}{c}\text { Rata-rata } \pm \\
\text { SD }\end{array}$ \\
& & $3,3685 \pm$ \\
Bendul Merisi & 30 & 0,20447 \\
& & $4,8003 \pm$ \\
& & 0,05641
\end{tabular}

Berdasarkan analisis statistik menunjukkan bahwa ada perbedaan yang signifikan dari kadar lemak susu yang berasal dari Bendul Merisi dan Nongkojajar $\mathrm{P}<0,01)$.
Tabel 2. Hasil nilai rata-rata berat jenis

\begin{tabular}{lcc}
\hline Perlakuan & Sampel & $\begin{array}{c}\text { Rata-rata } \pm \\
\text { SD }\end{array}$ \\
& & $1,028067 \pm$ \\
Bendul Merisi & 30 & 0,0025452 \\
& & $1,024767 \pm$ \\
Nongkojajar & 30 & 0,0011043
\end{tabular}

Berdasarkan analisis statistik menunjukkan bahwa tidak ada perbedaan yang signifikan dari berat jenis susu yang berasal dari Bendul Merisi dan Nonkojajar $\mathrm{P}<0,01)$.

\section{PEMBAHASAN}

Berdasarkan hasil pengujian menunjukkan bahwa nilai rata-rata kadar lemak yang berasal dari Nongkojajar adalah $4,8003 \pm 0,05641 \%$ dan rata-rata kadar lemak yang berasal dari Bendul Merisi adalah 3,3683 $\pm 0,20447 \%$. Kadar lemak kedua dataran tersebut mempunyai rata rata di atas standat SNI, Hasil analisa statistis menunjukan $\mathrm{P}<0,01$, P lemak $0,00<0,01$ yang berarti ada perbedaan yang sangat nyata dari kadar lemak susu yang berasal dari Nongkojajar, dan Bendul Merisi. Kriteria kadar lemak pada susu segar yang ditetapkan oleh SNI 3141.1:2011 adalah $3,0 \%$.

Berdasarkan tabel diatas, berat jenis tertinggi berasal dari Bendul Merisi yang berada diatas standar SNI yaitu dengan ratarata $1,028067 \pm 0,0025452$ dan nilai ratarata berat jenis dari Nongkojajar berada dibawah standar SNI, yang berarti adanya perbedaan yang sangat nyata dari berat jenis susu yang berasal dari Bendul Merisi dan Nongkojajar.

\section{KESIMPULAN}

Berdasarkan hasil penelitian terhadap perbandingan kadar lemak dan berat jenis pada susu sapi segar di Nongkojajar dan Bendil Merisi dapat disimpulkan bahwa Hasil kadar lemak susu segar yang terdapat pada Nongkojajar dan Bendul Merisi menunjukkan adanya perbedaan yang nyata. Dimana kadar lemak yang terdapat di Nongkojajar lebih tinggi di bandingkan di 
Bendul Merisi. Dikarenakan perbedaan pemberian rumput hijaun, masa laktasi dan suhu, faktor ini yang bisa mempengaruhi tinggi rendahnya kadar lemak pada peternakan yang ada di Nongkojajar maupun di Bendul Merisi. Hasil berat jenis susu segar yang terdapat di Bedul Merisi dan Nongkojajar meunjukkan adanya perbedaan yang sangat nyata. Dimana berat jenis yang terdapat di Nongkojajar berada dibawah SNI.

\section{REFERENSI}

Amrulloh, M. F., Surjowardojo, P., \& Setyowati, E. 2018. Produksi Dan Kualitas Susu Peranakan Friesian Holstein Pada Pemerahan Pagi Dan Sore (Ditinjau Dari Uji Berat Jenis, Kadar Lemak Dan Uji Reduktase). Jurnal Maduranch. 32(2):69-74.

Anang, A., Indrijani, H. \& Tasripin, D. 2010. Analisis Efek Tetap dalam Evaluasi Genetik Produksi Susu pada Sapi Perah Menggunakan Catatan Test Day di Indonesia. Jurnal Ilmu Ternak dan Veteriner. 15(2):138-146.

Anang, A., Indrijani, H. \& Tasripin, D. 2010. Analisis Efek Tetap dalam Evaluasi Genetik Produksi Susu pada Sapi Perah Menggunakan Catatan Test Day di Indonesia. Jurnal Ilmu Ternak dan Veteriner. 15(2):138-146.

Anonim. 1998. Standar Nasional Indonesia (SNI) 01-3141-1998 tentang Air Susu Murni.

Anonim. 2011 ${ }^{\text {a }}$ Budidaya Ternak Sapi Perah. BPP Pendayagunaan dan Pemasyarakatan Ilmu Pengetahuan dan Teknologi. http://ebookgratisan.net/budidayaternak-sapi-perah (diakses pada tanggal 15 Februari 2020).

Anoraga Jatayu dan Cahyono Susetyo 2017, Departemen Perencanaan Wilayah dan Kota, Fakultas Teknik Sipil dan
Perencanaan, Institut Teknologi Sepuluh Nopember (ITS)

Anugrah, T, G. 2012. Kualitas Susu Sapi Perah Fries Holland $(\mathrm{FH})$ yang Diberi Tepung Daun Murbei (Morus alba) dan Ampas Tahu dengan Level yang

Berbeda. [Skripsi]. Fakultas Peternakan. Universitas Hasanuddin Makkasar.

Badan Standarisasi Nasional. 2011. Standar Nasional Indonesia (SNI) Susu Segar bagian 1: Sapi 3141.1-2011. http://www.bsn.go.id. Diakses tanggal 1 Januari 2020.

Calderon,A., D.V. Armstrong, D.E. Ray,S.K. Denise, R.M. Enns and C.M. Howison. 2005. Productive and reproductive response of Holstein and Brown Swiss heat stressed dairy cows to two different cooling systems. J. Anim Vet 4:572-578.

Dobson, H., Ghuman, S. P. S., Prabhaker, S., Smith, R. F. 2003. A conceptual model of the influence of stress on female reproduction. reproduction. 125:151-163.

Dudi, Dedi R dan T. Dhalika, 2006. Evaluasi Potensi Genetik Sapi PeraFriesholland. Tesis Sekolah Pasca Sarjana Fakultas Peternakan Universitas Padjajaran. http:// pustaka. Undap. ac. id./wp-content/up loads. Diakses pada tanggal 17 Mei 2020.

Epaphras A., Karimuribo, E. D. and Msellem, S. N. 2009. Effect of season and parity on lactation of Crossbred Ayrshire cows reared under coastal tropical climatein Tanzania www.Irrd.org/Irrd16/6/epap16042.htm. Tanggal Akses 27 Februari 2020.

Gunawan Bambang. dan Nurlina. 2017. IMB Kelompok Peternakan Sapi Perah 
Di Bendul Merisi, Kelurahan Bendul Merisi, Kecamatan Wonocolo, Kota Surabaya. Fakultas Pertania, Universitas Merdeka Surabaya

Hadiwiyoto, S. 1994. Tehnik Uji Mutu Susu dan Hasil Olahannya. Liberty. Yogyakarta.

Irawan, F. 2010. Korelasi Produksi Susu dengan Status Fisiologis Sapi FH (Fries Holland) pada Saat Laktasi di UPTD Ruminansia Besar Dinas Petenakan Kabupaten Kampar. Skripsi. Program Studi Peternakan Fakultas Pertanian dan Peternakan Universitas Islam Negeri Sultan Syarif Kasim. Pekanbaru.

Karnaen dan J. Arifin. 2009. Korelasi nilai pemuliaan produksi susu sapi perah berdasarkan test day laktasi 1, laktasi 2, laktasi 3, dengan gabungannya. Animal Production 11:135-142.

Smith, D. B. dan S. Mangkoewidjojo. 1988. Pemeliharaan, Pembiakan dan Penggunaan Hewan Percobaan di Daerah Tropis, UI Press, Jakarta

Sugitha dan Djalil. 2010. Susu. //http://www.scribd.com/doc/60125528/ susu. [ 17 Januari 2020].

Sukmawati Ni Made Suci.2014. Faktor faktor yang Mempengaruhi Susunan dan Keadaan Air Susu. Fakultas Peternakan Universitas Udayana Denpasar.
Surdowardojo, Puguh. Aju, Tjatur, Nugroho. dan M. Nur. Ihsan. 2010. Pada berbagai paritas dan bulan laktasi di ketinggian tempat yang berbeda

Tawaf,Rochaidi.2011.SapiPerah Friesian Holstein.http://disnaksinjai.blogspot.co $\mathrm{m} / 2011 / 09 /$.

Triani. 2011. analisis produksi susu, persentase protein susu dan konsumsi hijauan sapi FH (Fries Holland) pada tingkat laktasi yang berbeda di UPT ruminansi besar dinas kabupaten Kampar. [Skripsi]. program studi peternakan Fakultas Pertanian dan Peternakan. Universitas Islam Sultan Syarif Kesim Riau.

Warni. 2014. Kualitas Susu Sapi Perah di Kabupaten Sinjai dan Kaitannya dengan Infeksi Listeria monocytogenes [Skrpsi]. Fakultas Peternakan. Universitas Hasanuddin makkasar.

Warni. 2014. Kualitas Susu Sapi Perah di Kabupaten Sinjai dan Kaitannya dengan Infeksi Listeria monocytogenes [Skrpsi]. Fakultas Peternakan. Universitas Hasanuddin makkasar.

Wulandari, F. 2012. Komposisi, Kesegaran Dan Dugaan Pemalsuan Susu Segar Sebagai Bahan Dasar Keju Pada Industri Pengolahan Susu (IPS). [Skripsi]. Fakultas Kedokteran Hewan. Institut Pertanian Bogor. 